\title{
The domain of olfaction in Basque*
}

Iraide Ibarretxe-Antuñano

University of Zaragoza - IPH

\section{Abstract}

This chapter analyzes the domain of olfaction in Basque. Stemming from Ibarretxe-Antuñano's $(1999,2013)$ previous work on smell verbs, it explores the role of other olfaction constructions in the encoding of physical and figurative meanings in data drawn from dictionaries and corpora. Results show that smell constructions encode two types of physical perceptual meaning and then develop their figurative meanings accordingly. Copulative perception is related to characteristics and feelings. Active / experience perception to information, cognition, and search. Negative connotations usually associated to this sense (i.e. 'to suspect') do not

\footnotetext{
${ }^{*}$ This research has been supported by grants FFI2013-45553-C3-1-P and FFI2017-82460-P from the Spanish State Research Agency and the European FEDER Funds. Warm thanks to: Kimi Akita, Joseba Lakarra, and Blanca Urgell. I would also like to thank the two anonymous reviewers for their sharp comments and the editors for their infinite patience and for their invitation to participate in the theme session 'Towards a Typology of Olfactory Expressions' at the SLE 2016 in Naples (Italy).
} 
necessarily hold in Basque. With respect to usage, few of these smell words are frequently used in present-day Basque, and some of them have undergone specialization and narrowing processes.

Keywords: smell, perception, metaphor, Basque, olfactory vocabulary

\section{Introduction}

This chapter focuses on the domain of olfaction in Basque, a language isolate spoken on the Western Pyrenees in Southwest Europe. More concretely, it explores the semantic extensions, both physical and figurative, of seventeen Basque olfactory nouns and their respective constructions. The chapter is organized as follows. Section 1 briefly introduces the topic of olfactory expressions across languages and offers an overview of previous work on the meanings of smell verbs in Basque. Section 2 is devoted to methodological issues such as the criteria used in the choice and organization of smell nouns and the procedure followed to extract and analyze information from data sources (dictionaries and corpora). Sections 3 and 4 discuss the semantic scope and the usage of the seventeen selected smell nouns, respectively. Finally, this chapter concludes with a summary of the main results and an exploration of some of the main areas that deserve further future research in the domain of smell in general and in Basque in particular. 


\section{Olfactory expressions: the case of smell verbs in Basque}

The domain of olfaction has been traditionally considered a more restricted lexical field with less lexical items available to describe odors as well as a weaker source domain for extended metaphorical meanings in comparison with the other senses (Caplan 1973; Sweetser 1990; Vanhove 2008; Viberg 1984). Although it is partially true that this domain in human beings is not as developed as other senses such as vision, research on less-known cultures and languages has shown that olfaction is not as restricted as it seems at first sight (see Aikhenvald \& Storch 2013; Classen et al. 1994; Drobnick 2006). For instance, the Ongee of the Andaman Islands in the South Pacific organize their lives around smell (Pandya 1993) as do the Chewong people in the Malay Peninsula (Classen et al. 1994), the Sereer Ndut of Senegal (Dupire 1987), and the Ndjuka of Surinam (Thoden van Velzen \& van Wetering 1988). Speakers of Jahai and Maniq, another two Aslian languages of the Malay Peninsula, count with a rich smell vocabulary of around twelve to fourteen terms that enables them to name and capture olfactory scents crucial in their environment (Burenhult \& Majid 2011; Majid \& Burenhult 2014; Wnuk \& Majid 2014).

At first sight, it might be surprising to read that there are languages with so many diverse specific smell terms. In languages such as English, the 
main linguistic mechanisms for describing odors are to use synesthetic terms such as pungent (from Latin pungent- 'pricking' that came into the language in the late $16^{\text {th }}$ century in the sense of 'very painful' or 'distressing'), to name the object that emits the odor (e.g. smell of an apple) or to simply categorize them as good or bad smells. However, what happens in the Aslian languages above is not an exotic exception. It can be also found in other parts of the world. Just a few examples. In Siberia, the Tofa language has a special suffix for smells -sig. Tofa speakers simply have to attach this suffix to any object to create a new smell term, e.g. ivi sig 'reindeer smell' (Harrison 2007: 213). In Africa, the Kapsiki / Higi of North Cameroon and North-Eastern Nigeria, distinguish fourteen types of smell some of which are encoded by ideophones (e.g. verrevère 'the smell of the civet'). These smells are linked to specific odorous objects, animals, or people (Van Beek 1992). In the Americas, the Incas had a large number of odor words in Quechua. González Holguín's (1608) 17 $7^{\text {th }}$ century dictionary compiles more than thirty verbs relating to the perception and production of smells. Similarly, Bellamy (this volume) shows that Purépecha, an isolate language of Michoacán (Mexico), also has several words to name types of smells. She identifies fourteen terms in present-day Purépecha, ten of which were already attested in a $16^{\text {th }}$ century dictionary.

One could think, nevertheless, that the richness of the semantic field of smell is restricted to either remote hunter / gatherer / pastoralist cultures (as the Ongee, Chewong, Jahai or Maniq), or ancient cultures (as the Inca). 
Alternatively, another pretext could also be to argue that it is just a question of being able to list different lexical items to convey different types of odors, that is, physical meanings.

However, as far as olfaction semantics is concerned, this is not the whole story. Ibarretxe-Antuñano (1999) is probably one of the first studies on smell from a semantic viewpoint that argued that smell is not necessarily the poor sister in the well-known and even better studied field of perception. Ibarretxe-Antuñano conducted a series of cross-linguistic studies on the polysemy of perception verbs in three European languages (English, Spanish, and Basque) from a cognitive semantic point of view. In this framework, polysemy is a ubiquitous phenomenon (see Cuyckens \& Zawada 2001; Gries 2015; Valenzuela 2017 for an overview). In a nutshell, the meanings that a given linguistic item develops are categorized around a schematic and / or prototypical meaning, structured by means of cognitive mechanisms such as metaphor and metonymy, and embodied, i.e. motivated and grounded in our sensori-motor and socio-cultural experience.

Taking Sweetser's (1990) pioneering work as a starting point, IbarretxeAntuñano $(1999,2013)$ shows that smell can be used metaphorically to codify meanings in the domain of cognition such as 'sensing', 'suspecting', and 'investigating' and that smell is not just related to negative characteristics. Sweetser (1990) had proposed the general MIND AS BODY metaphor to account for the pervasive tendency to recruit concepts and vocabulary from the more accessible physical and social world to refer to 
more abstract worlds of reasoning, emotion and conversational structure. Within this metaphor, Sweetser argues that vision is the sense linked to knowledge but that smell is just related to "bad character or dislikeable mental characteristics (e.g. stink) and the detection of such characteristics (e.g. the active verb smell)" (1990: 38).

Ibarretxe-Antuñano $(1999,2013)$ also studies the motivation for the semantic extensions in smell (and in the other senses). That is to say, the reasons why the sense of smell is related, for example, to 'intuitive knowledge' whereas the other senses are related to other types of knowledge: vision to 'reliable knowledge', hearing to 'indirect knowledge', and touch and taste to 'experiential knowledge' (Ibarretxe-Antuñano 2019). She argues that the grounding for extended meanings can be explained by the way speakers experience the senses in their cultures as well as by the way the human perceptual system works (Ibarretxe-Antuñano 2008). Accordingly, she develops an open list of prototypical properties based on both the physiology and psychology of the senses to account for the embodiment of perception meanings. These properties do not apply to all meanings at all times; they are selected in each case by means of so-called Property Selection Processes. ${ }^{1}$ For instance, the types of knowledge just

\footnotetext{
${ }^{1}$ Due to space restrictions, it is not possible to explain this model in detail. The interested reader can consult Ibarretxe-Antuñano (2019) for an up-to-date account of these properties and the Property Selection Processes.
} 
described above could be justified by the way humans perceive with the senses. Hence, the five senses share the property $<$ detection $>$ since they all are excellent means to perceive their own stimuli. However, they differ in the other properties (and their values) ${ }^{2}$ they take. Smell is good at detecting that something happens but bad at identifying the type of stimulus, the type of Object of Perception ( $<$ identification no $>$ ). Hearing depends on the Object of Perception (OP) since it is impossible to perceive a sound unless it is produced by a third element; as such, hearing is a mediated perception $(<$ directnesSno $>)$. Touch and taste require a direct physical contact with the OP $\left(<\right.$ contact $\left._{y e s}>\right)$. Vision is good at detecting and identifying stimuli, independent from the OP and free of contact.

The sense of smell is defined by several properties. It is $<$ internalyes $>$ because in order to perceive smells, it is necessary to inhale air into our nostrils, from the outside to our inside, and $<$ directyes $>$ because it is not a mediated perception. It is $<$ voluntaryno $>$ because a wide variety of odors are smelt throughout every day and night without necessarily being aware of them. On some occasions, however, the smelling can be conscious $\left(<\right.$ voluntary $\left.y_{\text {es }}>\right)$ as when a scent is sniffed at. Smell is a very sharp and

\footnotetext{
${ }^{2}$ Each property takes $a_{\text {yes, no, }}$ or empty value depending on whether the property applies to each sense; this is because each sense has its own characteristics and its own way of processing information. This diversity is reflected in the distribution of both properties and values that take the citation form $<$ property $_{\mathrm{yes}}>$ or $<$ property $_{\mathrm{no}}>$.
} 
quick sense when it comes to detect new odors $\left(<\right.$ detection $\left._{y e s}>\right)$ provided that the odor is in the vicinity $(<$ closenessyes $>)$ but, as mentioned above, it is not that good at identifying the type of odor ( $<$ identification $\left._{\text {no }}>\right)$. Smells are not categorized in the same way by every person; reactions to smell vary depending on the person's personal and unique odor / memory associations $\left(<\right.$ subjective $\left._{\text {yes }}>\right)$. Each of the semantic extensions in smell selects only some of those properties.

Ibarretxe-Antuñano's $(1999,2013)$ work is based on the analysis of three main Basque smell verbs: usaindu, usnatu (usnaka ibili), and usmatu. The general verb usaindu (usaitu, usandu, usindu) can cover the three-way classification of perception verb types based on the semantic roles of the perceptual subject (Gisborne 2010; Leech 1971; Lehrer 1990; Poutsma 1926; Rogers 1971; Viberg 1984; among others). It can be used in active perception, i.e. the smelling process is conscious and controlled by an agent (property $<$ voluntaryyes $>$ ), experience perception, i.e. the agent does not consciously control the smelling process (property $<$ voluntaryno $>$ ), and percept/copulative perception, ${ }^{3}$ i.e. the subjects are the stimuli of the

\footnotetext{
${ }^{3}$ Percept / copulative perception is also encoded in Basque by means of other constructions as shown later in this chapter (smell noun + the verb jarion / erion 'flow'). Recently, and probably due to language contact (see Berro 2015a, b), this perception also admits another construction with an ergative subject as in (i):
}

(i) Puruak txarto usaintzen $d u$ cigar.ERG badly smell.HAB AUX.TR 
smelling perception (property $<$ voluntaryno $>$ ). Examples (1)-(3) illustrate these three perception possibilities, i.e. active, experience, and percept / copulative, respectively. The other two verbs, usnatu (usnaka ibili) and usmatu, usually cover the active perception.

(1) Mikelek bere purua usaindu zuen Michael.ERG his cigar.ABS smell AUX.TR 'Michael smelt his cigar'

(2) Mikelek puruak usaindu zituen gelan Michael.ERG cigar.ABS.PL smell AUX.TR room.LOC 'Michael smelt cigars in the room'

(3) Gelan purua usaintzen da room.LOC cigar.ABS.SG smell.HAB AUX.INTR 'The room smells of cigar'

Table 1 presents the semantic scope (physical $(\mathrm{P})$ and figurative $(\mathrm{F})$ ) of smell verbs in Basque and the distribution of prototypical properties (motivation) as discussed in Ibarretxe-Antuñano's (1999, 2008, 2013, 2019) previous research.

\section{'It smells of cigar'}

Thanks to an anonymous reviewer for pointing out this possibility. 
Table 1: Meanings in Basque smell verbs. $(\mathrm{P})=$ physical, $(\mathrm{F})=$ figurative.

\begin{tabular}{|c|c|}
\hline Semantic scope & $\begin{array}{l}\text { Motivation } \\
\text { (selected prototypical } \\
\text { properties) }\end{array}$ \\
\hline to trail something $(\mathrm{P})$ & $<$ voluntaryyes $>,<$ detection $_{\text {yes }}>$ \\
\hline to investigate $(\mathrm{F})$ & $<$ voluntaryyes $>,<$ detection $_{\text {yes }}>$ \\
\hline to suspect $(F)$ & $\begin{array}{l}<\text { voluntaryyes }>,<\text { detection }_{\mathrm{yes}}>\text {, } \\
<\text { identification } \mathrm{no}>\end{array}$ \\
\hline to sense, to know intuitively $(\mathrm{F})$ & $\begin{array}{l}<\text { voluntaryyes }>,<\text { detection }_{\text {yes }}>\text {, } \\
<\text { identification } n \text { no }>\end{array}$ \\
\hline to guess, to realize $(\mathrm{F})$ & $\begin{array}{l}<\text { voluntary }_{y e s}>,<\text { detection }_{\text {yes }}>\text {, } \\
<\text { identification }_{\mathrm{no}}>\end{array}$ \\
\hline to become bad, to spoil, to corrupt $(\mathrm{F})$ & $<$ voluntaryno $>,<$ internalyes $>$ \\
\hline to be oblivious $(\mathrm{F})$ & $<$ voluntaryno $>,<$ briefnessyes $>$ \\
\hline to prophesy $(\mathrm{F})$ & $\begin{array}{l}<\text { voluntaryyes }>,<\text { detection }_{\text {yes }}>\text {, } \\
<\text { identification }_{n o}>\end{array}$ \\
\hline
\end{tabular}

This work left some areas underexplored. One of those caveats is the study of other olfaction related lexical items and constructions (beyond verbs) in the encoding of physical and figurative meanings in the Basque smell domain. This area is crucial because it directly raises several interrelated issues such as how many linguistic resources Basque has to describe the domain of olfaction, how many different meanings these resources develop and whether these meanings are related to specific resources or common to all of them, how many of these extended meanings are shared with other languages and how many are particular to Basque, and more generally, how salient this domain is in Basque. In what follows, I aim to provide new data to fill in this gap and, therefore, to provide a more comprehensive approach to the domain of olfaction in Basque. 


\section{Beyond verbs: smell nouns in Basque}

For this study, I have selected seventeen olfactory nouns. Basque is a very rich dialectal language (Zuazo 2013). The smell nouns under analysis sometimes include diatopic variants which only differ phonologically (e.g. lurrin / lurrun '(good) smell') but some other times, they also differ in meaning (e.g. kirats 'stench' in all varieties but also 'sadness' in northern varieties). In order to be both consistent and exhaustive, smell nouns with their own entry in the Orotariko Euskal Hiztegia (Mitxelena 1987-2005, see below) have been considered independent lexical items in this chapter (marked in bold below and treated as citation forms). Dialectal variants are provided in brackets and possible reconstructed forms in square brackets.

Basque olfactory nouns can be clustered together according to their possible etymological ${ }^{4}$ origin and meaning:

\footnotetext{
${ }^{4}$ Thanks to Joseba Lakarra and Blanca Urgell for their help. It is not easy to talk about etymology in Basque since written records before the $16^{\text {th }}$ century are scarce. All the information included here (etymology, first written occurrence date, variants) comes from Michelena (1990), the Orotariko Euskal Hiztegia (Mitxelena 1987-2005), and the Euskal Hiztegi Historiko-Etimologikoa (Lakarra et al. 2019). Readers interested in the history of
} Basque language, see Gorrochategui et al. (2018), Martínez-Areta (2013), Trask (1997). 
- The FIRST CLUSTER includes the word hats (ats, has) (and kir-ats). This is a native word, first documented in 1538 , related to concepts such as 'breath', 'whiff'.

- The SECOND CLUSTER contains two etymologically related words, urrin $\left(17^{\text {th }}\right.$ ct.) and lurrin (1562; lurrun, lurruin) [*lurruin]. Urrin means 'smell' and lurrin is also linked to the meaning 'vapor', 'steam'.

- The THIRD CLUSTER is composed of kirats (1545; kirets, karats, kiratz, karatz, kerats, kiats, keats), kino (mid-19 ${ }^{\text {th }}$ ct.; kheino, kio, kinu), kindu (1745), and keru (1745; kelu). These native words seem to come from *ken- 'smell'.

- The FOURTH CLUSTER is the most numerous and comprises usna (1715; usma 1745), suma (1745; soma), sunda (1800; suinda, zunda), susma (1802; susme), sumo (mid $\left.19^{\text {th }} \mathrm{ct}\right)$, sunja $^{\text {mt }}\left(\right.$ end $19^{\text {th }}$ ct.; sunya, sunia), susmo ${ }^{m t}$ (end $19^{\text {th }}$ ct.; susmu, zuzmo, zuzmu), usmo (1905; usno, uzmo), and susna (mid 20 ${ }^{\text {th }} \mathrm{ct}$.; susne). They are said to have derived from Greek osmáomai into Romance usmar. They generally refer to the sense of smell. ${ }^{5}$

\footnotetext{
This organization into five etymologically-based clusters will be useful to discuss meanings in Section 3.

${ }^{5}$ Items in this cluster are chronologically ordered. Some of the most recent words exclusively convey metaphorical meanings ('sagacity'; 'trait'; 'intuitive perception',
} 
- The FIFTH CLUSTER includes usain (1562; usain, usein, usei, usin) [*usaini], the native basic-level word that covers both 'smell' and 'sense of smell'.

In order to determine both the semantic scope and current usage / prominence of these smell nouns, two sources of data are employed: dictionaries and corpora. Among the former, two dictionaries are mainly consulted. First, the Orotariko Euskal Hiztegia (General Dictionary of the Basque Language) (OEH; Mitxelena 1987-2005). The OEH a sixteenvolume dictionary that compiles all the information available for each entry including not only diachronic and synchronic meanings but also attributed quotations, and second, the online version of Elhuyar Hiztegia (Elhuyar Dictionary) (ELH). The ELH is a trilingual (Basque, Spanish, French) synchronic general dictionary (91.000 entries) in Standard Basque.

As far as corpora are concerned, two main corpora are used. First, the XX. mendeko Euskararen Corpus Estatistikoa (Statistical Corpus of Twentieth Century Basque) (XXECE; UZEI 1987-2001). It covers all the $20^{\text {th }}$ century (divided into four periods: $1900-1939,1940-1968,1969-1990$, 1991-2001). It contains 4.658.036 words drawn from texts in six different

\footnotetext{
'suspicion'). This is marked with a superscript ${ }^{\mathrm{mt}}$. These words are included in this analysis because they nicely illustrate the path of semantic change for smell in this cluster. This issue will be discussed in Section 3.2.
} 
dialects and 14 genres. Second, the Egungo Testuen Corpusa (Corpus of Contemporary Basque) (ETC; Sarasola et al. 2001-2015). It covers the period from 2001 to 2015 . It contains around 270 million words drawn from $21^{\text {th }}$ century books and newspaper articles published in France and Spain.

The procedure is the following. First, each smell noun is checked out in the four resources ${ }^{6}$ in this order: OEH, ELH, XXECE, and ETC. The dictionaries provide us with information about the meanings and usages of each lexical item and then, the corpora with illustrative examples as well as quantitative data about the usage of these lexical items. Most importantly, these four resources are crucial to establish how prototypical these items are in present-day Basque for the encoding of olfactory terms (see Section 4).

Second, meanings in smell nouns are organized in two groups. Physical meanings include the three perceptual modalities (active, experience, copulative), and other possible physical semantic extensions. Figurative meanings, on the other hand, any non-physical (metaphorical) extended senses.

Third, verbal constructions with / derived from smell nouns included as lexical entries in the dictionaries consulted, a total of 62 items, and their

\footnotetext{
${ }^{6}$ These are just four resources from the range of available materials in Basque. Future studies should incorporate further sources such as dictionaries (e.g. Oyharçabal 2009-2013; Sarasola 2008- ) and corpora (e.g. Euskara Institutoa 2013; Sarasola et al. 2001-2007) to test and enhance the results discussed in this chapter.
} 
meanings are checked out and arranged into these two meaning groups (physical and figurative). Basque has two main morphological strategies for the creation of smell verbal constructions: by suffixation (verbs, e.g. usain$d u$ (smell.noun+verbal suffix) 'to smell') and by the addition of a light / lexical verb (complex predicates, e.g. usain egin (smell.noun+make) 'to smell') (see Hualde \& Ortiz de Urbina 2003). Besides these strategies, verbal valency is also crucial for the encoding of perceptual modalities. Intransitive monovalent and bivalent structures are linked to copulative perception (e.g. usaintzen da (smell.HAB AUX.INTR.3SG.ABS) 'it smells of...') and transitive and ditransitive structures to active / experience perception (e.g. usaintzen $d u$ (smell.HAB AUX.TR.3SG.ABS.3SG.ERG) 'he smells (something)' (see Etxepare 2003, for information on valency). Table 2 lists some of the most common smell verbal constructions under consideration in this work.

Table 2: Smell verbal constructions in Basque.

\begin{tabular}{|c|c|c|}
\hline \multicolumn{2}{|r|}{ Morphological strategy } & Example \\
\hline \multirow{3}{*}{ 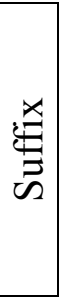 } & $-t u,-d u$ 'VERBALIZER' & $\begin{array}{l}\text { usaindu 'to smell' (experience) } \\
\text { lurrindu 'to scent' } \\
\text { urrintsutu 'to fill a place with a bad smell' }\end{array}$ \\
\hline & -datu, -katu 'CAUSATIVE' & $\begin{array}{l}\text { urrindatu (TR) 'to smell (active)' } \\
\text { urrindatu (INTR) 'to become smelly' }\end{array}$ \\
\hline & -(e)ztatu 'INST+VERBALIZER' & urrineztatu 'to wear perfume' \\
\hline \multirow{2}{*}{ 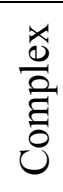 } & egin 'make' & $\begin{array}{l}\text { kino egin 'to smell (copulative)' } \\
\text { lurrin egin 'to make a perfume' } \\
\text { susna egin 'to smell (active)' }\end{array}$ \\
\hline & ibili 'activity verb, walk' & usna-musnaka ibili 'to sniff around' \\
\hline
\end{tabular}




\begin{tabular}{|l|l|}
\hline izan (TR) 'have' & soma izan 'to sense' \\
\hline agertu 'appear' & kerua agertu 'to show rancor' \\
\hline ekarri 'bring' & kirats ekarri 'to fill with smell' \\
\hline eman 'give' & usain eman 'to scent' \\
\hline aditu 'listen' & usna aditu 'to smell (active)' \\
\hline entzun 'hear, listen' & usain entzun 'to smell (active, experience)' \\
\hline erion 'ooze, flow (substance)' & - i (DAT) usaina erion 'to smell (copulative) of' \\
\hline hartu 'take' & $\begin{array}{l}\text { usna hartu 'to smell (active)' } \\
\text { usainak hartu 'to become smelly' }\end{array}$ \\
\hline jo 'hit, strike, give' & usmoz jo 'to sense' \\
\hline
\end{tabular}

\section{The semantic scope of olfactory vocabulary}

This section explores the meanings, physical and figurative, found in the seventeen olfactory nouns, as well as in a selection of their most common verbal constructions.

\subsection{Physical meanings}

As far as physical meanings are concerned, olfactory nouns encode four main meanings: the smell itself, which can be bad, good, or neither (which will be called "neutral" here); the object that gives off smell, the sense of smell, and the action of smelling. Table 3 gives the physical semantic scope of the seventeen smell nouns under analysis.

Meanings in Table 3 are nicely distributed across the five smell noun clusters. CLUSTERS 1, 2, and 3 mainly encode smells. CLUSTER 1, hats, is only 
related to bad smells as most members in CLUSTER 3 as in (4); kino is also used for neutral smells in the OEH.

(4) Gela hatsez eta kiratsez zegoen $[\mathrm{ELH}]$
room smell.INST and smell.INST was
'The room stank'

@@ Insert Table 3 here

In the case of CLUSTER 2, urrin can be used to describe any type of smell as in the OEH examples in (5). Lurrin, on the other hand, is related to both good and bad smells in the OEH but only with good smells in the ELH. Lurrin has eventually metonymically extended its meaning to encode the object that gives off a scent, i.e. perfume (e.g. lurrinontzia (smell.container) 'bottle of perfume').

(5) a. Neutral smell

olio-urrina 'smell of oil'

b. Good smell

arrosa-urrina 'smell of roses'; urrin goxoa 'sweet smell'

c. Bad smell

ustel-urrina 'smell of something rotten'; urrin txarra 'bad smell' 
CLUSTER 4 is occasionally related to neutral smell (e.g. usnia dago 'there is a smell') and bad smell (e.g. lizun-sunda 'smell of mold'), but most of its members are linked to the sense of smell as in (6).

(6) Antilope emea, adarrik ezean bista argi-argiaz, antelope calf.ABS horn.PART lack sight clear-clear.INST belarri zorrotz-zorrotzez eta usna fin-finez ear sharp-sharp.INST and smell fine-fine.INST baliatuko da horien ihes aldegiteko [XXECE] serve.FUT AUX.INTR those.GEN escape leave.NMLZ 'The antelope calf, in lack of horns, will use his very sharp sight, his very acute ear and his very fine smell to escape'

Finally, CLUSTER 5, usain, covers all the above-mentioned meanings; smells themselves and the sense of smell as in (7) and (8) respectively.

(7) a. Neutral smell
Gure mendi-erriak
garo usaia
our mountain-village.PL.ERG ${ }^{7}$ fern smell.ABS

\footnotetext{
${ }^{7}$ The verbs erion and jarion 'flow' show a dative / ergative alternation attested since the $19^{\text {th }}$ century (see Fernández \& Ortiz de Urbina 2010). I would like to thank one of the reviewers for pointing out this fact.
} 


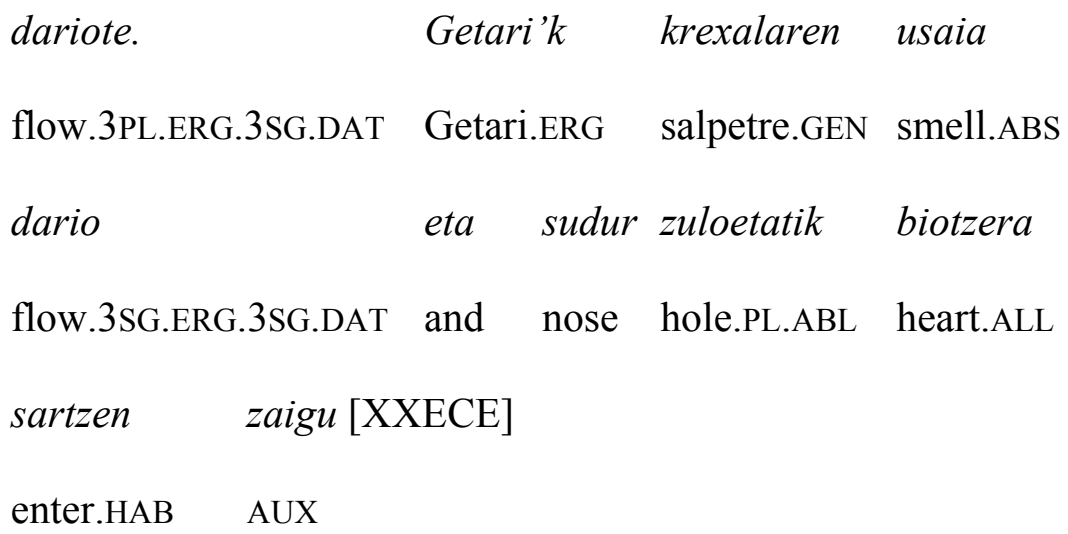

'Our mountain villages give off a smell of fern. Getaria gives off a smell of sea water and it goes straight from our nostrils into our heart'

b. Good smell

Sukalde usain goxoaren laguntzaz [ETC]

kitchen smell sweet.GEN help.INST

'With the help of the sweet smell of the kitchen'

c. Bad smell

Odol ustelduaren usaina [ETC]

blood rot.GEN smell.ABS

'a smell of rotten blood'

(8) [Zakurrek] usai oneko sudurra dute [OEH]

dog.PL.ERG smell good.ADN nose.ABS AUX.TR

'Dogs have a good sense of smell'

These semantic extensions arise two important issues. First, the role of compositional polysemy; that is, the graded interaction of the semantic 
content of a lexical item and its co-occurring elements in triggering the overall meaning of a complex linguistic structure. Smell is usually related to bad smells in the literature, both physically and figuratively (cf. Sweetser 1990), but it does not seem to be the case in Basque either physically or figuratively as discussed in Section 3.2. Bad smells are usually encoded by CLUSTERS 1 and 3. However, CLUSTERS 2, 3, and 5 do not necessarily refer to bad smells. It depends on the object that emits the odor. In other words, the meaning is compositional. If the smell is related to a rose, the smell is a 'perfume', if the smell is related to a corpse, the smell is a 'stench', and if the smell is related to oil, that is, a 'neutral' substance, the smell is simply an odor, not good not bad.

The 'no-bad-preference' in Basque smell words in CLUSTERS 2, 4, and 5 becomes very evident in smell derived words such as denominal adjectives with the suffix -tsu 'having, abundant in' and with the suffix -dun 'having, possessing' as illustrated in Table 4.

Table 4: Smell -tsu and -dun adjectives.

\begin{tabular}{|l|l|l|l|}
\hline $\begin{array}{l}\text { Etym. } \\
\text { Clusters }\end{array}$ & $\begin{array}{l}\text { Smell } \\
\text { noun }\end{array}$ & Smell adjectives with -tsu & Smell adjectives with -dun \\
\hline CLUSTER 1 & hats & --- & --- \\
\hline CLUSTER 2 & urrin & $\begin{array}{l}\text { urrintsu } \\
\text { 'odorous' } \\
\text { 'fragrant', 'aromatic' } \\
\text { 'stinking' }\end{array}$ & $\begin{array}{l}\text { urrindun } \\
\text { 'odorous' } \\
\text { ''fragrant', 'aromatic' } \\
\text { 'stinking' }\end{array}$ \\
\cline { 2 - 4 } & lurrin & $\begin{array}{l}\text { lurrintsu } \\
\text { 'very fragrant' } \\
\text { 'very stinking' }\end{array}$ & $\begin{array}{l}\text { lurrindun } \\
\text { 'odorous' } \\
\text { 'fragrant', 'aromatic' }\end{array}$ \\
\hline
\end{tabular}




\begin{tabular}{|c|c|c|c|}
\hline & & & 'stinking' \\
\hline \multirow{4}{*}{ CLUSTER 3} & kirats & $\begin{array}{l}\text { kiratsu } \\
\text { 'stinking', 'foul', 'reeking' }\end{array}$ & $\begin{array}{l}\text { kirasdun } \\
\text { 'stinking', 'foul', 'reeking' } \\
\text { 'bitter, tart (flavor)' }\end{array}$ \\
\hline & kino & $\begin{array}{l}\text { kinotsu } \\
\text { 'stinking', 'foul', 'reeking' }\end{array}$ & $\begin{array}{l}\text { kinodun } \\
\text { 'stinking', 'foul', 'reeking' } \\
\text { 'with a bad flavor' }\end{array}$ \\
\hline & kindu & --- & --- \\
\hline & keru & $\begin{array}{l}\text { kerutsu [ETC] } \\
\text { 'foul' }\end{array}$ & $\begin{array}{l}\text { kerudun } \\
\text { 'stinking', 'foul', 'reeking' } \\
\text { 'resentful', 'bitter' }\end{array}$ \\
\hline \multirow{9}{*}{ CLUSTER 4} & usna & --- & $\begin{array}{l}\text { usnadun } \\
\text { 'with a good sense of } \\
\text { smell' } \\
\text { 'with a good intuition', } \\
\text { 'clairvoyance', 'sixth } \\
\text { sense' }\end{array}$ \\
\hline & suma & $\begin{array}{l}\text { sumatsu } \\
\text { 'sharp', 'clever', } \\
\text { 'sagacious' }\end{array}$ & $\begin{array}{l}\text { sumadun } \\
\text { 'with a good sense of } \\
\text { smell' } \\
\text { 'with a good intuition', } \\
\text { 'clairvoyance', 'sixth } \\
\text { sense' }\end{array}$ \\
\hline & sunda & --- & $\begin{array}{l}\text { sundadun } \\
\text { 'with a smell of...' }\end{array}$ \\
\hline & susma & --- & --- \\
\hline & sumo & --- & --- \\
\hline & sunja & --- & --- \\
\hline & susmo & $\begin{array}{l}\text { susmotsu } \\
\text { 'distrusful', } \\
\text { 'apprehensive', } \\
\text { 'suspicious' }\end{array}$ & --- \\
\hline & usmo & $\begin{array}{l}\text { usmotsu } \\
\text { 'very instinctive', 'very } \\
\text { intuitive' }\end{array}$ & --- \\
\hline & susna & --- & --- \\
\hline CLUSTER 5 & usain & $\begin{array}{l}\text { usaintsu } \\
\text { 'odorous' } \\
\text { 'fragrant', 'aromatic' } \\
\text { 'stinking' }\end{array}$ & $\begin{array}{l}\text { usaindun } \\
\text { 'odorous' } \\
\text { 'fragrant', 'aromatic' }\end{array}$ \\
\hline
\end{tabular}


The second issue refers to the semantic changes in smell nouns, especially those in CLUSTERS 2 and 4. A comparison between the meanings provided in each dictionary (OEH vs. ELH) shows that nouns in these two clusters used to cover a wider range of meanings. In the $\mathrm{OEH}$, lurrin encodes both good and bad odors, whereas usna, sunda, susmo, and susna mean 'neutral odor'. Most of the nouns in CLUSTER 4 (except sunda and susna) also refer to 'olfaction'. The meaning of these nouns has narrowed down in the ELH. Lurrin only refers to good smells. None of the nouns in CLUSTER 4 refers to neutral smells, and only usma, suma, and usmo refer to olfaction.

In relation to verbal constructions with these smell nouns, there are eight main physical meanings: the three main perceptual modalities (active, experience, copulative), to scent (good smell), to make smelly (bad), to fill a place with an odor, to become oneself odorous, and to make a perfume. Table 5 presents the distribution of these physical meanings across the smell verbal constructions.

A general overview of the distribution of these meanings per cluster reveals that CLUSTERS 1,2, and 3 are linked to the copulative perceptual meanings, as well as to give or cause odor-related semantic extensions: to scent, to make smelly, to fill with smell, and to make perfume. CLUSTER 4 is related to both active and experience meanings, whereas CLUSTER 5, once again, covers the whole range of meanings.

This distribution of meanings seems to correspond to the meaning of noun these verbs derived from. CLUSTERS 1, 2, and 3 codify types of smells 
and their verbal counterparts, the emission and causing of odors. CLUSTER 4, on the other hand, is related to the act of olfaction and the sense of smell and verbal constructions are related to active and experience smell. CLUSTER 5 covers all possibilities and so do its verbal constructions. This distribution becomes evident if the same type of verbal construction is examined. For instance, lurrinkatu and usainkatu, both have the cumulative suffix -ka and verbal suffix $-t u$, but the former means 'to perfume', 'to diffuse a fragrance' and the latter, 'to sniff at', 'to smell carefully'. Similarly, smell derived verbs with the suffix $-t u /-d u$ in the first three clusters trigger copulative meanings as well as to cause / give odors, active / experience meanings in the second cluster, and all of them in the fifth cluster as illustrated in (9).

(9) a. Clusters 1, 2, 3

Urrindu 'to give off a bad smell', 'to scent', 'to make smelly', 'to become smelly'

Lurrindu 'to scent', 'to fill with smell'

Kirastu 'to give off a bad smell', 'to make smelly', 'to become smelly', 'to fill with smell'

Kinotu 'to give off a bad smell', 'to become smelly'

Kindutu 'to become smelly'

Kerutu 'to become smelly'

b. Cluster 4

Usnatu 'to smell (act.)', 'to smell (exp.)' 
Sumatu 'to smell (act.)'

Sundatu 'to smell (act.)'

Susmatu 'to smell (act.)'

Sunjatu 'to smell (act.)'

Usmotu 'to smell (act.)', 'to smell (exp.)'

c. Cluster 5

Usaindu 'to smell (act.)', 'to smell (exp.)', 'to smell (cop.)', 'to scent', 'to make smelly', 'to become smelly', 'to fill with smell'

On other occasions, however, certain constructions are exclusively linked to certain meanings. Hence, active smell is lexicalized by means of constructions formed by a smell noun plus verbs such as aditu 'hear', 'listen' (e.g. usna aditu) and entzun 'hear' (e.g. usain entzun), or a smell noun in the locative case plus the verb ibili 'activity', 'walk' (e.g. usnan / suman / sundan / susmoan / usmoan / susnan / usainean ibili 'smell', 'sniff') as illustrated in (10) and (11), respectively.

(10) Bi makinen bidez Smell Machines,
two machine.GEN path.INST Smell Machines
bisitariak anbar eta bioleten lurrina aditu
visitor.ERG ambar and violet.GEN smell.ABS hear
dezake gelan sartu edo atera orduko [ETC]
can.TR room.LOC enter or exit hour.ADN


'Thanks to two machines, Smell Machines, the visitor can smell the scent of ambar and violets either when he comes in or out of the room'

(11) Usnan dabil txakurra lurrean [ETC] smell.LOC walks dog.ABS ground.LOC 'The dog is sniffing the ground'

Copulative smell, on the other hand, is construed with the verb jarion / erion 'ooze', 'flow (substance)' as in (12) and (13).

(12) Lonjari

arrain usaina dario; ez

fishmarket.DAT fish smell.ABS flow.3SG.ERG.3SG.DAT NEG da seinale txarra $[\mathrm{ETC}]$

is sign bad.ABS

'The fishmarket smells of fish; that's not a bad sign'

(13) Itzuli naizenerako Armando etxean dago return AUX.INTR.ALL.ADN Armando house.LOC is hara hor amantal zuriarekin, sukaldeari over.there.ALL there apron white.COM kitchen.DAT irin eta ogi usain atsegina dariola [ETC] flour and bread smell nice.ABS flow.3SG.ERG.3SG.DAT 'By the time I come back, Armando is at home, there, with his white apron, the kitchen nicely smelling of flour and bread' 
Both the distribution of meanings across clusters and their respective constructions are crucial in the explanation of figurative semantic extensions, as discussed in the next Section 3.2.

\section{@@ Insert Table 5 here}

\subsection{Figurative meanings}

Basque smell nouns convey around twelve main non-physical meanings. Table 6 compiles these meanings and their distribution. ${ }^{8}$ As in the case of physical meanings, each cluster clearly prefers certain extended meanings. Hence, CLUSTERS 1, 2, and 3, which were related to types of smells, tend to encode meanings related to feelings and emotions: keru is usually associated with rancor and kindu with grief and sorrow (e.g. kindua bihotzean [OEH] (smell.ABS heart.LOC) 'sorrow in heart').

\footnotetext{
${ }^{8}$ The analysis of corpora has unveiled further meaning extensions, not documented in the two dictionaries consulted, for some of these smell nouns. I have included those semantic extensions in this analysis and marked them in the tables with the letter C.
} 
Another set of meaning extensions is what is called here "defining characteristics". In this general category, smell nouns refer to a property (or properties) that clearly identifies or remembers the main and typical traits that describe the defined object. In (14), for instance, maitasun benetakoaren lurrina refers to the essence of what can define a true love.

(14) Oroitzapen hari esker maitasun
reminder that.over.here.DAT thank love
benetakoaren lurrina ezagutu zuen agureak
true.GEN smell.ABS know AUX.TR old.man.ERG
$[\ldots][$ ETC $]$

'Thanks to that memory, the old man knew the smell of true love'

When bad smell nouns ${ }^{9}$ such as kirats are used, these characteristics are negative instead as in (15), where Fundamentalismoaren kiratsa 'the smell of fundamentalism' refers to some of the main traits of fundamentalism.

\footnotetext{
${ }^{9}$ The same applies to the second-cluster smell noun sunda. One of its physical meanings is bad smell, and it can also be used in this metaphorical sense as illustrated in (ii).
}

(ii) Horiek denek gezur sunda bat zeukaten niretzat ere [ETC] those.ERG all.ERG lie smell one had I.BEN also Lit. 'All of those had a smell of lie for me' 
(15) Italiako lehen ministro Silvio Berlusconik, berriz, Italy.ADN first minister Silvio Berlusconi.ERG new.INST gogor gaitzetsi zuen Europako Legebiltzarraren hard disapprove AUX.TR Europe.ADN Parliament.GEN jarrera: “Fundamentalismoaren kiratsa $d u$ " [ETC] posture.ABS fundamentalism.GEN smell.ABS AUX.TR 'The Italian Prime Minister Silvio Berlusconi, in turn, has roundly disapproved the posture taken by the European Parliament: "It stinks of fundamentalism",

If the smell noun is used in a negative construction, then it refers to a hint, a bit of something (usually translated as nothing or not even a bit) as in (16).

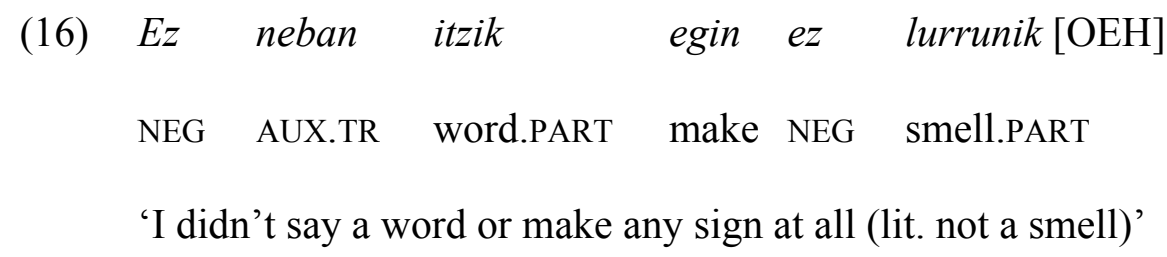

CLUSTER 4, which was related to neutral smell and olfaction, develops three main general meanings. The first one is "information" as illustrated in (17). Smell conveys the idea of a trace; that is to say, an indication that something happened or existed, as well as the idea of a clue; that is, information that helps to reveal something that has not yet happened. 
(17) Haize epelak badu halako udaberri-susmo

wind warm.ERG does.has that.ADN spring-smell

goiztar bat $[\mathrm{OEH}]$

early one

'Warm wind is indeed an early sign for spring'

The second general meaning has to do with (unconscious and keen) reasoning and thinking ('instinct', 'sagacity', 'intuition', 'suspicion'). Smell nouns in this second cluster were also related to the sense of smell, and it seems that this is linked to this kind of unconscious capacity to gather intuitive information as in (18) and to have a good instinct as in (19).

(18) Hemen lapurketa bat egon den susmoa here theft one be AUX.INTR.COMP smell.ABS daukat, eta abokatu naizen aldetik, kasu hau have.1SG and lawyer am.COMP side.ABL case this argituko dudan hitza ematen dizuet [XXECE] clear.FUT AUX.TR.COMP word.ABS give.HAB AUX 'I have the feeling that a theft has been committed here, and as a lawyer, I promise you that I will solve this case'

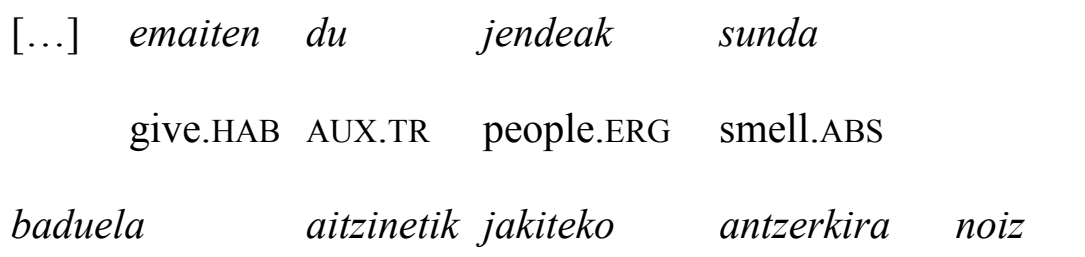


does.has.COMP front.ABL know.NMLZ theatre.ALL when ez etorri eta noiz saldoan etorri $[\ldots][\mathrm{ETC}]$

NEG come and when crowd.LOC come

'It seems that people do know beforehand when not to come to theatre and when to flock to it'

In this cluster, smell nouns such as sunja, sunda, and suma not only refer to sagacity but have also undergone a generalization semantic change to extend their meanings to general perception and intuitive body sense.

Finally, the third general meaning is related to the concept of searching. The smell noun is usually in the locative case as in zorionaren usmoan (happiness.GEN smell.LOC) 'in search for happiness'.

CLUSTER 5 covers all of the above-mentioned meanings. It means 'search' in (20), 'instinct' in (21) and, "defining characteristics" as ‘identifying properties' in (22) and as 'a hint, a bit of something' in (23).

(20) Juninho brasildarra golaren usainean egon zen Juninho brazilian.ABS goal.GEN smell.LOC be AUX.INTR sarri $[\mathrm{ETC}]$

often

'The Brazilian [player] Juninho is very often in search of a goal'

(21) Benetako intelektuala zela, usain politiko true intellectual.ABS was.COMP smell political 
fina zuela, garaian garaiko egoerara

acute.ABS had.COMP time.LOC time.ADN situation.ALL

egokitzeko gauza zela [ETC]

adapt.NMLZ thing was.COMP

'That he was a real intellectual, that he had a keen political

instinct, that he was able to adapt himself to the needs of the time at the right time'

(22) Herria arraun usaina berreskuratzen ari

town.ABS rowing smell.ABS recover.HAB be.busy

da, baita San Pedrorekiko lehia historikoa

AUX.INTR also San Pedro.COM.ADN rivalry historical.ABS

ere $[\mathrm{ETC}]$

also

'The town is recovering its rowing character, even the old rivalry towards San Pedro’

(23) Ez du langile-usainik ere gizon horrek [EHL]

NEG has worker-smell.PART even man that.ERG

'That man is not very industrious at all (lit. not to have even a smell of a worker)'

Similarly, the semantic extensions in verbal constructions reflect the meanings developed in their noun counterparts. There are four main groups of meanings. The first is related to feelings and is mainly connected to 
CLUSTER 3. As a consequence, these feelings are usually negative as in the case of 'to rancor' and 'to feel sad' in (24).

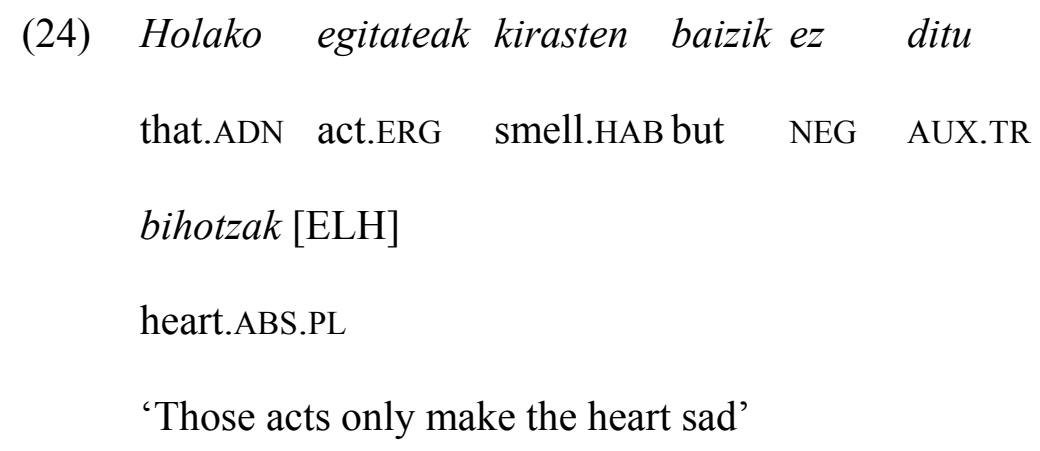

Another group is related to the adoption of defining characteristics and is linked to CLUSTERS 3 and 5. On some occasions, if the smell is negative, as in CLUSTER 3, the verbal construction usually means 'to corrupt', 'to spoil', 'to become bad' as illustrated in (25).
(25) Orain, mitologia errepublikarra ez kirasteko, now mythology republican.ABS NEG smell.NMLZ
Gobineau bakarrik aipatzen da arrazismo
Gobineau only mention.HAB AUX.INTR racism
frantsesaren aita zatar bezala $[\ldots][$ ETC $]$
french.GEN father ugly as
'In order not to spoil all the Republican mythology, Gobineau is now mentioned as the sole unpleasant father of French racism'


On some other cases, smell refers to 'having certain typical and distinctive characteristics' as in (26) and (27).

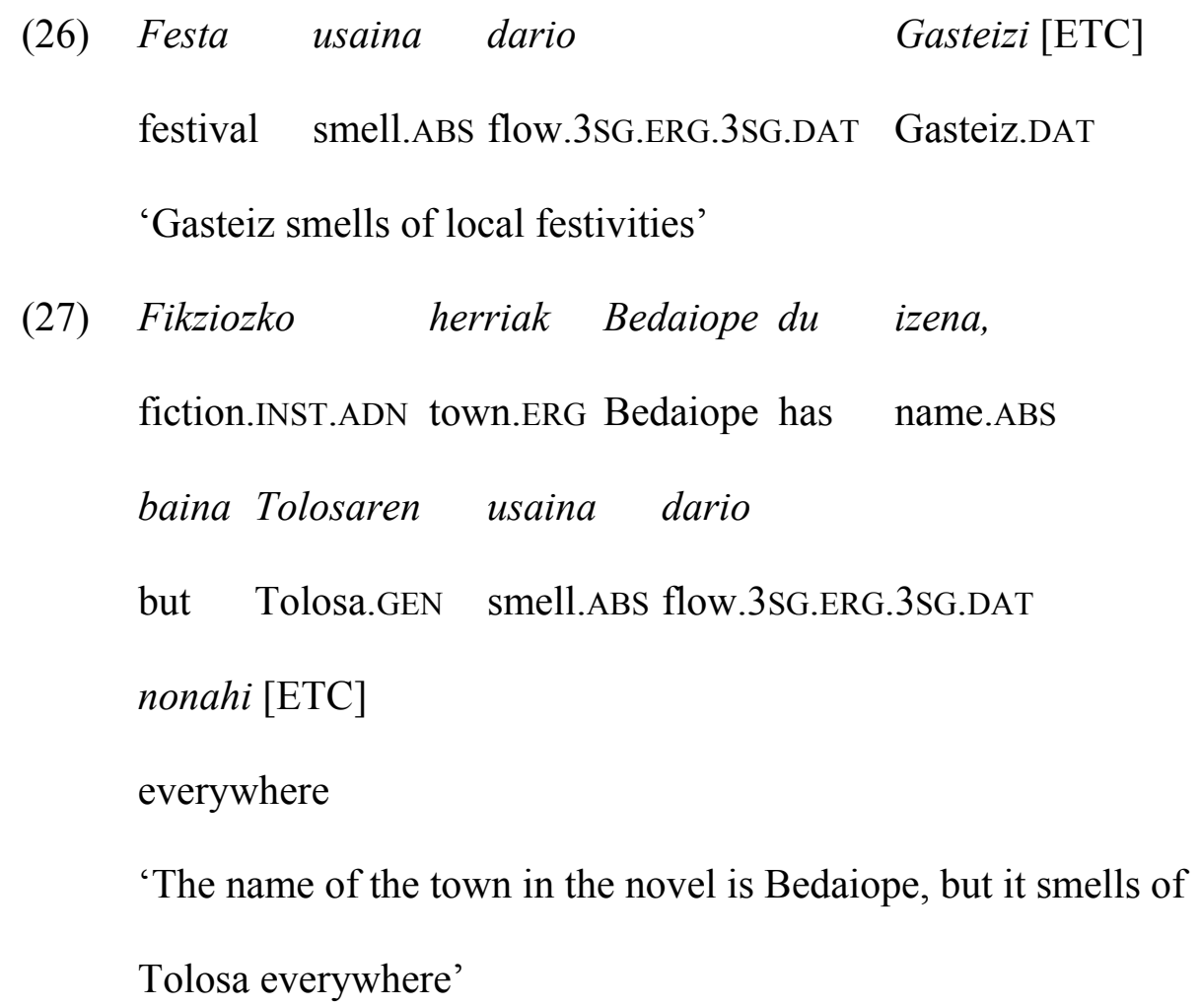

The third group of meanings is connected to the concept of search.

Meanings such as 'search for something' and 'investigate' are classified in this group and encoded by CLUSTERS 4 and 5.

$\begin{array}{lrrrr}\text { (28) Polizia leku guztietatik } & \text { zebilen } & \text { usnaka, eta } \\ \text { police place } & \text { all.PL.ABL } & \text { walked.3SG } & \text { smell.ITE and } \\ \text { komandokoak } & e z & \text { ziren } & \text { segurtasunezko } \\ \text { commando.ADN.ABS.PL NEG } & \text { AUX.INTR safety.INST.ADN }\end{array}$




\section{pisutik irteten [ETC] \\ flat.ABL exit.HAB}

'Police has been sniffing around everywhere, and command members did not leave the safe-house'

Finally, the last big group contains meanings related to cognition, i.e. reasoning and thinking processes. CLUSTERS 4 and 5 usually encode these meanings. There are several possible specific meanings included in this group: 'to sense', 'to detect', 'to imagine', 'to suspect', 'to realize', 'to be oblivious is not to smell'. The following examples illustrate these semantic extensions.

(29) Beste akordioren bat egon daitekeelausaintzen
other agreement.GEN one be can.COMP smell.HAB
duzu, ala? [ETC]
AUX.TR or
'Can you sense whether there is going to be any other new
agreement?'
Idazten ez ezik, albisteak usaintzen ere
write.HAB NEG only news.ABS.PL smell.HAB also
maisua zen Capote, eta Clutter familiaren
master.ABS was Capote and Clutter family.GEN
etxeko sarraskiaren berri izan orduko jakin


house.ADN massacre.GENnews have as.soon.as know

zuen hura liburu handia izan

AUX.TR that.over.there book big.ABS be

zitekeela [ETC]

could.COMP

'Capote was not only good at writing but also at detecting news, and as soon as he heard about the Clutter family murders he knew that could make a great book'

(31) General Motorsek eta Chryslerrek porrot egiteko

General Motors.ERG and Chrysler.ERG failure make.NMLZ arriskua usaindu behar izan $d u \quad$ Etxe danger.ABS smell have AUX AUX.TR House

Zuriak jarreraz aldatzeko [ETC]

White.ERG position.INST change.NMLZ

'The White House had to suspect that both General Motors and Chrysler were in danger of bankruptcy to change their position'

(32) Aitortu behar dugu hasiera-hasieran ez confess have AUX.TR beginning-beginning.LOC NEG genuela usaindu ere egin zer arlotako AUX.TR.COMP smell even make what sloppy.ADN berbak ziren horiek guztiak word.ABS.PL were.3PL those all.ABS 
'We have to confess that right at the beginning we did not realize how sloppy all those words were'

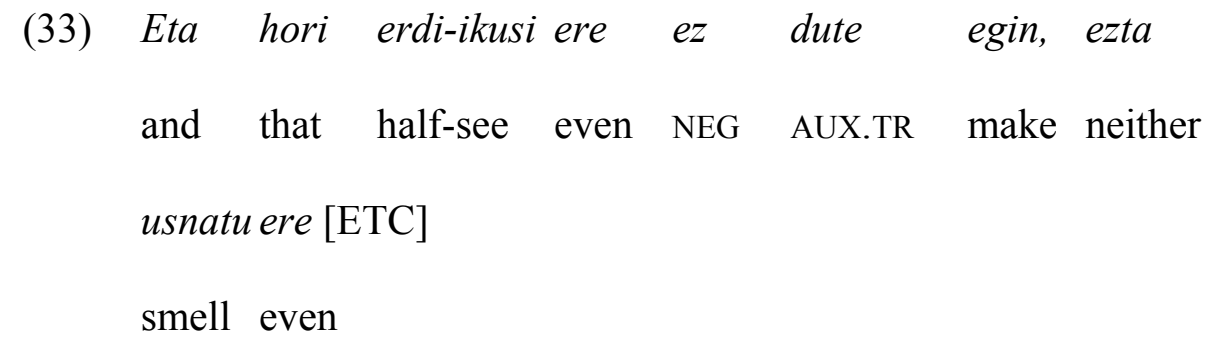

The specific choice of the type of thinking and reasoning process that the smell construction encodes in these examples seems directly connected to the semantics of the co-occurring elements. As happened in physical meanings, if the object being smelt is negative the meaning it triggers is 'to suspect', but if, on the other hand, the object of perception is positive, smell can be paraphrased as 'to sense'. Therefore, it seems that, at least in Basque, smell does not share this, sometimes overgeneralized, negative character. Smell simply evokes a quick, sharp, and intuitive thinking. The kind of thinking that arises when, either based on left traces or future signs, we sense that something has happened or will take place.

@@ Insert Table 6 here

@@ Insert Table 7 here 


\section{Just a word on the use of olfactory vocabulary}

In the previous sections, the scope of olfactory vocabulary has been examined. So far, this examination has focused on the "type" of semantic extensions these linguistic structures can convey in Basque. Tables 3-7 summarize not only the range of meanings in smell but also how these meanings are distributed across olfactory nouns and verbal constructions. The next step should be the study of these semantic extension occurrences. In other words, the investigation of how salient and frequent these structures and their corresponding meanings are in Basque. Unfortunately, a thorough and sound corpus analysis lies beyond the scope of this chapter. However, a quick look at this olfactory vocabulary in the four data sources employed in this study already sheds some light on this issue. Table 8 contains the occurrences of these nouns in these four sources.

Table 8: Presence or occurrence of Basque olfactory nouns in dictionaries and corpora.

\begin{tabular}{|l|l|l|l|l|}
\hline Smell noun & OEH & ELH & XXECE & ETC \\
\hline hats & yes & yes (Bizkaian) & 109 tokens & 300 tokens \\
\hline urrin & yes & yes (Northern) & 20 tokens & 757 tokens \\
\hline lurrin & yes & yes & 22 tokens & $\mathbf{4 6 6 6}$ tokens \\
\hline
\end{tabular}




\begin{tabular}{|c|c|c|c|c|}
\hline kirats & yes & yes & 53 tokens & 2623 tokens \\
\hline kino & yes & yes (Northern) & 0 token & 5 tokens \\
\hline kindu & yes & no & 0 token & 0 token \\
\hline keru & yes & yes (Northern) & 4 tokens & 89 tokens \\
\hline usna & yes & yes (Northern) & 6 tokens & 330 tokens \\
\hline suma & yes & yes & 6 tokens & 0 token \\
\hline sunda & yes & yes (Bizkaian) & 3 tokens & 144 tokens \\
\hline susma & yes & no (only derived) & 0 token & 0 token \\
\hline sumo & yes & no & 2 tokens & 24 tokens \\
\hline sunja $^{m t}$ & yes & no & 0 token & 0 token \\
\hline susmo $^{m t}$ & yes & yes & 173 tokens & 13750 tokens \\
\hline usmo & yes & yes & 3 tokens & 0 token \\
\hline susna & yes & no & 0 token & 0 token \\
\hline usain & yes & yes & 18698 tokens & 304 tokens \\
\hline
\end{tabular}

Results in Table 8 show that the usage distribution within smell nouns is clearly not balanced. Some lexical nouns such kindu, susma, and sunja are not present in recent sources (ELH, XXECE, ETC), while others, lurrin, kirats, susmo, and usain steadily appear in the four sources. It is interesting to notice the shift in the use of these latter items in the two corpora. While usain is clearly the olfactory noun with the highest frequency in the XXECE, its frequency has decreased in the more recent ETC corpus. The opposite holds for the other three.

A look at the evolution of their meanings might offer a tentative explanation. As shown in Section 3, there has been a semantic change in lurrin. According to the $\mathrm{OEH}$, this noun is used to encode neutral, good, and bad odors. However, its meaning has narrowed down and specialized as documented in the ELH. Lurrin generally refers to perfumes and pleasant scents (see also Strik Lievers, this volume, on diachrony of olfactory 
expressions). Similarly, susmo used to refer to the sense of smell and smell in general, but now the ELH only keeps two extended meanings, 'suspicion' and 'intuition' as a first meaning, and 'clue' and 'trace' as a second meaning. A quick look at the examples in both corpora confirms these semantic changes. Lurrin, kirats, and susmo are mainly used to refer to perfume, unpleasant odors, and intuitions / suspicions, respectively. These results are only exploratory and need to be supported by a future detailed qualitative and quantitative study based not only on the XXECE and ETC but also on further available corpora (e.g. Sarasola et al. 2001-2007; Euskara Institutoa 2013).

\section{Final remarks and future work: smell in language and culture}

This chapter has explored the semantic domain of smell in seventeen olfactory nouns and sixty-three derived verbal constructions in Basque. It has been shown that these smell related nouns can be clustered together around five etymologically different sources: CLUSTER 1, hats (native) 'breath', 'whiff' > 'bad smell'; CLUSTER 2, lurrin, urrin (native) 'smell' > 'scent (perfume)'; CLUSTER 3, kirats, kino, kindu, keru (possibly from the root *ken-) 'smell' > 'stench'; CLUSTER 4, sunda, sunja, sumo, susma, susmo, susna, susno, soma, usmo, usna (Greek osmáomai > Romance 
usmar) 'smell', 'sense of smell'; and CLUSTER 5, usain (native?), basic-level word.

These nouns and their corresponding verbal constructions encode the three-way classification of perception (active, experience, percept / copulative). Nouns in CLUSTERS 1 to 3 cover percept / copulative perception. They used to refer both positive and negative smells indistinctly, but their meanings have narrowed down so that they are specialized as either bad (CLUSTER 1 and CLUSTER 3) or good (CLUSTER 2) in present-day Basque. Nouns in CLUSTER 4 could be used either to describe the sense of smell or the active result of the perception; in other words, active and experience perception. Finally, usain in CLUSTER 5 is the main basic-level smell noun in Basque and covers all the three above-mentioned types.

It has been argued that semantic extensions (physical and figurative) depend on the type of smell perception the nouns they derived from encode. Meanings related to characteristics and feelings extend from percept / copulative type smell nouns (CLUSTERS 1,2,3,5), whereas meanings linked to information, cognition, and investigation come from active and experiencer type of smell nouns (CLUSTERS 4, 5). Figure 1 recapitulates these extended meanings. 
Results in Figure 1 suggest that Basque has several basic terms for smell. However, the list of terms is not exhaustive. One possible way to expand this research is to explore the vocabulary available in Basque to describe types of smells. The lexical items under analysis in this chapter cover basic smells (neutral, good, bad), but not more specific scents as, for example, English synesthetic adjectives pungent and sweet. Basque also seems to "recycle" labels from other senses. For example, garratz and min describe pungent smells but also sour and bitter tastes. A more in-depth analysis of these labels is needed.

Ideophones, that is, expressive marked linguistic units with a dramaturgic depictive function, could be another niche to find more olfactory lexical resources in Basque. Research in some African and Asian languages has shown that ideophones are paramount resources to describe sensory perception (see also Lambert-Brétière, this volume, on ideophones in Fon).

Ideophones are used to talk about all sensory varieties beyond sound. This type of words is reported to encode sensory characteristics. For

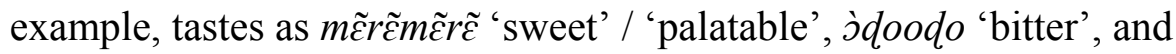
nyagbalaa 'a term conflating sour and salty' in Siwu (Dingemanse 2011), tsékétseke 'sweet' in Chichewa (Kulemeka 1993), and dzudzur 'sour', jaja: 'foul-tasting', and lemlem 'sweet' in Khaling-Rai (Lahaussois 2017). Smells as shireshire 'the smell of the feces of various animals' and hes 'hese 'the smell of roast food (peanunts, meat)' in Kapsiki (Van Beek 1992) and 
$k d u c k d e c$ 'experience of bitter smells from various places', ghuup 'acrid odor', ghoop 'intense acrid odor', and ghppp 'very intense acrid odor' in Semai (Tufvesson 2011). Textures (touch) as hwahwalaa 'rough' and (kplo)kplsplo 'smooth' in Nyagbo (Essegbey 2013) and zarazara 'rough', nurunuru 'slimy', and subesube 'smooth' in Japanese (Akita 2009, pers. comm.). But ideophones are also used to refer to perceptual processes as vivi 'be(come) sweet' in Ewe (Ameka 2001), lemne 'to taste' in Khaling-Rai (Lahaussois 2017), irundu 'smelling good' in Tamil (Abbi 1994), and kunkun 'sniff-sniff' in Japanese (Akita 2009, pers. comm.).

Basque is reported to be a language with a rich ideophone inventory (Ibarretxe-Antuñano 2017). Therefore, perception ideophones are likely to encode sensory characteristics, e.g. kirrin-karran 'squeak', 'creak' and dizdiz 'sparkle', 'scintillation', 'shine', but also sensory-related physical (and metaphorical processes), as puz-puz-puz 'the sound of a dog sniffing at a trail'; 'to sniff around'. The number, semantic scope, and usage of these sensory ideophones are open questions for future study.

Figure 1 also shows a fairly rich bunch of semantic extensions, mainly related to emotions and cognition. These extended meanings connect bad smell with negative characteristics for emotion meanings but not necessarily for the other extensions (e.g. cognition meanings). This is an important finding since smell is usually related to negative connotations in the literature. These data provide evidence against this tendency. To try to impose a (universal) negative value to the sense of smell is faulty in two 
ways. First, because this type of analysis ignores the linguistic context as well as the pragmatic affordances in which the smell word is used. Consider I smell trouble vs. I smell triumph; trouble brings in negative connotations and triumph positive connotations. That is why, the former can be paraphrase as 'I suspect' and the second 'I foresee'.

Second, because what is good or bad, or in olfactory terms 'pleasant' and 'repellent', is culture-specific. A long time ago, Osborne (1977) already argued that the division of odors into pleasant and unpleasant might be applicable universally but that it was too simplistic. In most cultures, there are 'good' odors (positive values, pleasant, fragrant...) usually associated with birth and growth in nature and 'bad' odors (negative values, repellent, stinky...) generally linked to death in nature. What is not shared universally is which odors fall into these two (graded and diffused) categories and the kind of evocative qualities they have, and as Osborne (1977: 47) says "these [qualities] appear to be particularly prominent in smells".

Literature on cultures beyond the Western world has long shown that smell is not only crucial in the organization of life and cosmology, but also that both the discrimination and the categorization of smells vary across cultures and change over time (see Ackerman 1990; Chrea et al. 2004; Classen et al. 1994). For instance, the smell of excrements and corpses could be widely considered 'repellent'; however, cultures such as the Ndjuka, a Maroon group in Surinam (Thoden van Velzen \& van Wetering 1988), do not share this view (see also Pawłowska 2014; Homan et al. 
2017). Most importantly, on the basis of this discrimination and categorization of smells, objects and entities related to smells are equally discriminated and categorized. Smell is also used to categorize people into social groups or castes: ‘stinky’ people vs. 'good smell' people. The Dassanetch of Ethiopia (Almagor 1987) and the Kapsiki of Cameroon (Van Beek 1992) are illustrative examples; fishermen and blacksmiths (rerhè) belong to the first group, pastoralists and "normal" Kapsiki (melu) go in the second group. What is more, as Van Beek (1992) reports, it is not only that the Kapsiki are divided into two 'smell' groups, the rerhè and the melu, the way people in each group categorize the same smell is different (see also Dobkin de Rios \& Hayden 1985). Odor categorization and discrimination also varies across times. Western culture relies mostly in other senses, mainly vision, and seems to have "forgotten" smell. As Burton (1976: 110) nicely puts it: "Man has quite a good nose, but... during the course of evolution he has left the world of smells". Studies on earlier stages of Western civilization (Corbin 1986; Detienne 1977; Ong 1991) illustrate not only this decline of olfaction, but also that the categorization and conceptualization of olfaction and smells were closer to these non-Western cultures than we may think. Nowadays, Basque is not different from other Western cultures. Sight is probably a much more trusted sense that smell is. However, what the language demonstrates is that other senses such as smell used to play a bigger role. After all, languages are encapsulators of culture; 
fragile and precious bottles of human knowledge. All we have to do is to learn how to open them up and let their scent enrapture and captivate us.

\section{Abbreviations}

$1 / 2 / 3$ - 1st/2nd/3rd person, ABL - ablative, ABS - absolutive, ADN adnominal, ALL - allative, AUX - auxiliary, B - Bizkaian dialect, BEN benefactive, C - corpora, COM - commitative, COMP - complemetizer, DAT dative, ELH - Elhuyar Hiztegia, ERG - ergative, ETC - Egungo Testuen Corpusa, F - figurative, FUT - future, GEN - genitive, HAB - habitual, INST instrumental, INTR - intransitive, ITE - iterative, LOC - locative, M masculine, MT - metaphorical, N - Northern varieties, NEG - negation, NMLZ - nominalization, OEH - Orotariko Euskal Hiztegia, OP - object of perception, P - physical, PART - partitive, PL - plural, SG - singular, TR transitive, XXECE - XX. mendeko Euskararen Corpus Estatistikoa.

\section{Primary sources}

Euskara Institutoa. 2013. Euskal Klasikoen Corpusa (EKC) ['Classic Basque Corpus']. UPV / EHU, Euskara Institutoa, $<$ http://www.ehu.eus/ehg/kc/> (13 December 2017). 
Sarasola, Ibon / Pello Salaburu \& Josu Landa. 2001-2007. Ereduzko Prosa Gaur (EPG) ['Contemporary Reference Prose']. UPV / EHU, Euskara Institutoa, <http://www.ehu.eus/euskaraorria/euskara/ereduzkoa/> (13 December 2017).

Sarasola, Ibon / Pello Salaburu \& Josu Landa. 2001-2015. Egungo Testuen Corpusa (ETC) ['Corpus of Contemporary Basque']. UPV / EHU, Euskara Institutoa, <https://www.ehu.eus/etc/> (13 December 2017).

UZEI. 1987-2001. XX. mendeko Euskararen Corpus Estatistikoa ['Statistical Corpus of $20^{\text {th }}$ Century Basque']. UZEI / Euskaltzaindia, $<$ http://xxmendea.euskaltzaindia.net/Corpus/> (13 December 2017).

\section{Dictionaries}

Elhuyar. n.d. Elhuyar hiztegiak online, <https://hiztegiak.elhuyar.eus/> (13 December 2017).

Lakarra, Joseba A. / Julen Manterola \& Iñaki Segurola. 2019. Euskal Hiztegi Historiko-Etimologikoa (EHHE-200) ['Historicaletymological Dictionary of the Basque Language (HEDB-200)']. Bilbo: Euskaltzaindia.

Mitxelena, Koldo. 1987-2005. Orotariko Euskal Hiztegia ['General Dictionary of the Basque Language'] Bilbo: Euskaltzaindia, <www.euskaltzaindia.eus/oeh> (13 December 2017). 
Oyharçabal, Beñat (ed.). 2009-2013. Nola Erran. Frantses-Euskara Hiztegi Elektronikoa ['How to speak. A French-Basque Electronic Dictionary'], <http://www.nolaerran.org/> (13 December 2017). Sarasola, Ibon. 2008- . Egungo Euskararen Hiztegia ['A Dictionary of Contemporary Basque']. UPV / EHU, Euskara Institutoa, $<$ https://www.ehu.eus/eu/web/eins/egungo-euskararen-hiztegia-eeh$>$ (13 December 2017).

\section{References}

Abbi, Anvita. 1994. Semantic Universals in Indian Languages. Shimla: Indian Institute of Advanced Study.

Aikhenvald, Alexandra Y. \& Anne Storch (eds) 2013. Perception and Cognition in Language and Culture [Brill's Studies in Language, Cognition and Culture 3]. Leiden: Brill.

Ackerman, Diane. 1990. The Natural History of the Senses. New York: Random House.

Akita, Kimi. 2009. A Grammar of Sound-Symbolic Words in Japanese: Theoretical Approaches to Iconic and Lexical Properties of Mimetics. PhD dissertation, Kobe University.

Almagor, Uri. 1987. The cycle and stagnation of smells: Pastoralistsfishermen relationships in an East African society. Res 13: 106-121. 
DOI: https://doi.org/10.1086/RESv13n1ms20166765

Ameka, Felix. 2001. Ideophones and the nature of the adjective word class in Ewe. In Ideophones [Typological Studies in Language 44], F. K. Erhard Voeltz \& Christa Kilian-Hatz (eds), 25-48. Amsterdam: John Benjamins. DOI: https://doi.org/10.1075/tsl.44.04ame

Berro, Ane. 2015a. Breaking verbs. From Event Structure to Syntactic Categories in Basque. PhD dissertation, UPV / EHU and Université Bordeaux Montaigne (UBM).

Berro, Ane. 2015b. Egoera predikatu berriak euskaraz ['New stative predicates in Basque'] Lapurdum 3: 11-25.

Burenhult, Niclas \& Asifa Majid. 2011. Olfaction in Asian ideology and language. Senses and Society 6(1): 19-29.

DOI: https://doi.org/10.2752/174589311X12893982233597

Burton, Robert. 1976. The Language of Smell. London: Routledge \& Kegan Paul.

Caplan, David. 1973. A note on the abstract readings of verbs of perception. Cognition 2(3): 269-277.

DOI: https://doi.org/10.1016/0010-0277(72)90035-2

Chrea, Christelle / Dominique Valentin / Claire Sulmont-Rossé / H. Ly Mai / D. Hoang Nguyen \& Hervé Abdi. 2004. Culture and odor categorization: Agreement between cultures depends upon the odors. Food Quality and Preference 15(7-8): 669-679.

DOI: https://doi.org/10.1016/j.foodqual.2003.10.005 
Classen, Constance / David Howes \& Anthony Synnott. 1994. Aroma: The Cultural History of Smell. London: Routledge.

Corbin, Alain. 1986. The Foul and the Fragant: Odours and French Social Imagination. Leamington Spa: Berg.

Cuyckens, Hubert \& Britta E. Zawada (eds). 2001. Polysemy in Cognitive Linguistics [Current Issues in Linguistic Theory 177]. Amsterdam: John Benjamins. DOI: https://doi.org/10.1075/cilt.177

Detienne, Marcel. 1977. The Gardens of Adonis: Spices in Greek Mythology. Atlantic Highlands, NJ: The Humanities Press.

Dingemanse, Mark. 2011. Ideophones and the aesthetics of everyday language in a West-African society. Senses and Society 6(1): 77-85. DOI: https://doi.org/10.2752/174589311X12893982233830

Dobkin de Rios, Marlene \& Brian Hayden. 1985. Odorous differentiation and variability in the sexual division of labor among hunter / gatherers. Journal of Human Evolution 14(3): 219-228.

DOI: https://doi.org/10.1016/S0047-2484(85)80063-4

Drobnick, Jim. 2006. The Smell Culture Reader. Leamington Spa: Berg.

Dupire, Marguerite. 1987. Des Goûts et des odeurs: classifications et universaux. L'Homme 27(104): 5-25.

DOI: https://doi.org/10.3406/hom.1987.368892

Essegbey, James. 2013. Touch ideophones in Nyagbo. In Selected Proceedings of the 43rd Annual Conference on African Linguistics: Linguistic Interfaces in African Languages, Ọlanikẹ Ọla Orie \& 
Karen W. Sanders (eds), 235-243. Somerville, MA: Cascadilla Proceedings Project.

Etxepare, Ricardo. 2003. Valency and argument structure in the Basque verb. In A Grammar of Basque [Mouton Grammar Library 26], José Ignacio Hualde \& Jon Ortiz de Urbina (eds), 363-426. Berlin:

Mouton de Gruyter.

DOI: https://doi.org/10.1515/9783110895285.363

Fernández, Beatriz \& Jon Ortiz de Urbina. 2010. Datiboa hiztegian ['The dative in the lexicon']. Bilbo: UPV / EHU.

Gisborne, Nikolas. 2010. The Event Structure of Perception Verbs. Oxford: Oxford University Press.

González Holguín, Diego. 1608. Vocabulario de la lengua general de todo el Perú llamada lengua qquichua o del Inca ['Vocabulary of the general language of Peru called qquichua language or that of the Inca']. Los Reyes (Lima): Francisco del Canto.

$<$ http://bvpb.mcu.es/es/consulta/registro.cmd?id=406594> $>(13$

December 2017).

Gorrochategui, Joaquín / Iván Igartua \& Joseba A. Lakarra 2018.

Euskararen historia / Historia de la lengua vasca ['History of the Basque language']. Gasteiz: Eusko Jaurlaritza.

Gries, Stephan Th. 2015. Polysemy. In Handbook of Cognitive Linguistics [Handbooks of Linguistics and Communication Sciences 39], Ewa 
Dąbrowska \& Dagmar Divjak (eds), 472-490. Berlin: Mouton de Gruyter. DOI: https://doi.org/10.1515/9783110292022-023

Harrison, K. David. 2007. When Languages Die. The Extinction of the World's Languages and the Erosion of Human Knowledge. New York: Oxford University Press.

Homan, Phillip / Ely A. Benjamin / May Yuan / Tobias Brosch / John Ng / Yaacov Trope \& Daniela Schiller. 2017. Aversive smell associations shape social judgment. Neurobiology of Learning and Memory 144: 86-95. DOI: https://doi.org/10.1016/j.nlm.2017.07.004

Hualde, José Ignacio \& Jon Ortiz de Urbina (eds). 2003. A Grammar of Basque [Mouton Grammar Library 26]. Berlin: Mouton de Gruyter. DOI: https://doi.org/10.1515/9783110895285

Ibarretxe-Antuñano, Iraide. 1999. Metaphorical mappings in the sense of smell. In Metaphor in Cognitive Linguistics [Current Issues in Linguistic Theory 175], Raymond W. Jr. Gibbs \& Gerard J. Steen (eds), 29-45. Amsterdam: John Benjamins.

DOI: https://doi.org/10.1075/cilt.175.03iba

Ibarretxe-Antuñano, Iraide. 2008. Vision metaphors for the intellect: Are they really cross-linguistic? Atlantis 30(1): 15-33.

Ibarretxe-Antuñano, Iraide. 2013. The power of the senses and the role of culture in metaphor and language. In Sensuous Cognition: Explorations into Human Sentience: Imagination, (E)motion and Perception [Applications of Cognitive Linguistics 22], Rosario 
Caballero \& Javier Díaz-Vera (eds), 109-133. Berlin: Mouton de Gruyter. DOI: https://doi.org/10.1515/9783110300772.109

Ibarretxe-Antuñano, Iraide. 2017. Basque ideophones from a typological perspective. Canadian Journal of Linguistics / Revue canadienne de linguistique 62(2): 196-220. DOI: https://doi.org/10.1017/cnj.2017.8 Ibarretxe-Antuñano, Iraide. 2019. Perception metaphors in cognitive linguistics: Scope, motivation, and lexicalization. In Perception metaphors [Converging Evidence in Language and Communication Research 19], Laura J. Speed / Carolyn O’Meara / Lila San Roque \& Asifa Majid (eds), 43-64. Amsterdam: John Benjamins.

Kulemeka, Andrew Tilimbe Clement. 1993. The Status of the Ideophone in Chichewa. PhD dissertation, Indiana University.

Lahaussois, Aimée. 2017. Ideophones in Khaling Rai. Linguistics of the Tibeto-Burman Area 40(2): 179-201.

DOI: https://doi.org/10.1075/ltba.17005.lah

Leech, Geoffrey. 1971. Meaning and the English Verb. London: Longman. Lehrer, Adrianne. 1990. Polysemy, conventionality, and the structure of the lexicon. Cognitive Linguistics 1(2): 207-246.

DOI: https://doi.org/10.1515/cogl.1990.1.2.207

Majid, Asifa \& Niclas Burenhult. 2014. Odors are expressible in language, as long as you speak the right language. Cognition 130: 266-270. DOI: https://doi.org/10.1016/j.cognition.2013.11.004 
Martínez-Areta, Mikel (ed). 2013. Basque and Proto-Basque: LanguageInternal and Typological Approaches to Linguistic Reconstruction. Frankfurt: Peter Lang.

DOI: https://doi.org/10.3726/978-3-653-02701-3

Michelena, Luis. 1990. Fonética histórica vasca ['Basque historical phonetics']. Donostia: Gipuzkoako Foru Aldundia.

Ong, Walter J. 1991. The shifting sensorium. In The Varieties of Sensory Experience. A Sourcebook in the Anthropology of the Senses, David Howes (ed), 25-30. Toronto: University of Toronto Press.

Osborne, Harold. 1977. Odours and appreciation. The British Journal of Aesthetics 17(1): 37-48.

DOI: https://doi.org/10.1093/bjaesthetics/17.1.37

Pandya, Vishvajit. 1993. Above the Forest: A Study of Andamanese Ethnoanemology, Cosmology and the Power of Ritual. Delhi: Oxford University Press.

Pawłowska, Kamilla. 2014. The smells of Neolithic Çatalhöyük, Turkey:

Time and space of human activity. Journal of Anthropological Archaeology 36: 1-11.

DOI: https://doi.org/10.1016/j.jaa.2014.07.001

Poutsma, Hendrik. 1926. A Grammar of Late Modern English. Part II: The Parts of Speech. Section II. Groningen: Nordhoff.

Rogers, Andrew. 1971. Three kinds of physical perception verbs. Chicago Linguistics Society 7: 206-223. 
Sweetser, Eve E. 1990. From Etymology to Pragmatics. Metaphorical and Cultural Aspects of Semantic Structure [Cambridge Studies in Linguistics 54]. Cambridge: Cambridge University Press.

DOI: https://doi.org/10.1017/CBO9780511620904

Thoden van Velzen, Hendrik U. E. \& Wilhelmina van Wetering. 1988. The Great Father and the Danger: Religious Cults, Material Forces, and Collective Fantasies in the World of the Surinamese Maroons. Dordrecht: Fortis.

Trask, Robert L. 1997. A History of Basque. London: Routledge.

Tufvesson, Sylvia. 2011. Analogy-making in the Semai sensory world. Senses and Society 6(1): 86-95.

DOI: https://doi.org/10.2752/174589311X12893982233876

Valenzuela, Javier. 2017. Meaning in English: An Introduction. Cambridge: Cambridge University Press.

Van Beek, Walter E. A. 1992. The dirty smith: Smell as a social frontier among the Kapsiki / Higi of North Cameroon and North-Eastern Nigeria. Africa 62(1): 38-58. DOI: https://doi.org/10.2307/1160063

Vanhove, Martine. 2008. Semantic associations between sensory modalities, prehension and mental perceptions: A crosslinguistic perspective. In From Polysemy to Semantic Change: Towards a Typology of Lexical Semantic Associations [Studies in Language Companion Series 106], Martine Vanhove (ed), 343-370. Amsterdam: John Benjamins. DOI: https://doi.org/10.1075/slcs.106.17van 
Viberg, Åke. 1984. The verbs of perception: A typological study. In Explanations for Language Universals, Brian Butterworth / Bernard Comrie \& Östen Dahl (eds), 123-162. Berlin: Mouton de Gruyter. DOI: https://doi.org/10.1515/9783110868555.123

Wnuk, Ewelina \& Asifa Majid 2014. Revisiting the limits of language: The odor lexicon of Maniq. Cognition 131(1): 125-138. DOI: https://doi.org/10.1016/j.cognition.2013.12.008

Zuazo, Koldo. 2013. The Dialects of Basque. Reno: Center for Basque Studies. 